Pamiętnik Literacki 2012, 1, s. 239-257

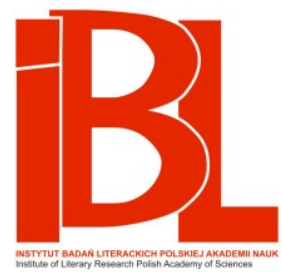

\title{
Trudna przyjaźń
}

\section{Dmitrij Fiłosofow - Maria Dąbrowska -}

Stanisław Stempowski

Piotr Mitzner 
Pamiętnik Literacki CIII, 2012, z. 1

PL ISSN 0031-0514

PIOTR MITZNER

(Uniwersytet Kardynała Stefana Wyszyńskiego, Warszawa)

\author{
TRUDNA PRZYJAŹŃN \\ DMITRIJ FIŁOSOFOW - MARIA DĄBROWSKA - STANISŁAW STEMPOWSKI
}

\begin{abstract}
Jest w Warszawie ulica Polna. Prowadzi ona na tor wyścigów konnych i dalej na lotnisko. Jednym słowem, w dal, która zdaje się nieskończona. Zrozumiałe, że na Polnej zawsze jest wietrznie i, co zadziwiające, wiatr tam zawsze wieje w oczy ${ }^{1}$, obojętnie, w którą stronę byście szli. Przy tej ulicy, pod numerem 40 od dawna mieszka znana polska pisarka Maria Dąbrowska.
\end{abstract}

- tak rozpoczyna się nie dokończony szkic Na wietru Dmitrija Fiłosofowa o Nocach i dniach ${ }^{2}$.

Ten przybysz, rosyjski emigrant - krytyk i redaktor - zostawił głębokie ślady w kulturze polskiej. Znawcy twórczości Marii Dąbrowskiej, Jerzego Stempowskiego, Marii i Józefa Czapskich, a także badacze zajmujący się rosyjską porewolucyjną diasporą sygnalizowali to już wielokrotnie, często przywołując fragmenty Dzienników Dąbrowskiej i słusznie sugerując, że postać Sergiusza Demidowa z Przygód człowieka myślacego wzorowana jest na osobie Fiłosofowa ${ }^{3}$.

Oparte jedynie na dziennikach pisarki przedstawienie relacji między Fiłosofowem a Dąbrowską i Stanisławem Stempowskim okazuje się jednak niesatysfakcjonujące. Pełniejsze dać może dopiero lektura listów. Tak się szczęśliwie złożyło, że w Dziale Rękopisów Biblioteki Uniwersytetu Warszawskiego ${ }^{4}$ i w zbiorach Muzeum Literatury ${ }^{5}$ znajduje się 65 listów Fiłosofowa do Dąbrowskiej i Stanisława Stempowskiego z lat $1926-1939^{6}$. Do listów od rosyjskiego przyjaciela oboje

Nb. czwarta część Nocy i dni nosi tytuł Wiatr w oczy.

2 Rękopis w posiadaniu B. Mikułowskiej.

3 Na temat relacji Dąbrowska-Fiłosofow zob. G. B o r k o w s k a, Maria Dąrowska i Stanisław Stempowski. Kraków 1999. - I. O b łą k o w s k a - G a la n c i a k: Dymitr Fiłosofow i Maria Dąbrowska. Z historii polsko-rosyjskich kontaktów kulturalnych w Dwudziestoleciu międzywojennym. „Acta Polono-Ruthenica” IV, 1999; Gorzkie gody... Publicystyczna i literacka działalność Dymitra Fiłosofowa na emigracji. Olsztyn 2001.

4 Korespondencja S. Stempowskiego i M. Dabrowskiej z D. Fiłosofowem z lat 1926-1939. Bibl. Uniwersytetu Warszawskiego, sygn. 1561. Ponadto: jeden list do S. Stempowskiego w teczce poświęconej sprawie S. B r z o z o w s k i e g o (sygn. 1543), odpisy fragmentów listów Stempowskiego do Fiłosofowa (sygn. 1541) i jeden (nie wysłany?) Dąbrowskiej (sygn. 1561).

5 Korespondencja S. Stempowskiego i M. Dąbrowskiej z D. Fiłosofowem. Muzeum Literatury im. Adama Mickiewicza w Warszawie, sygn. inw. 4608.

6 Listy te zostały opublikowane przez J. S. D u r r a n t a pt. Nieizdannyje piśma D. W. Fiłosofowa („Russian Studies”. Jeżekwartalnik russkoj fiłołogii i kultury, t. 3, nr 1. Sankt Pietierburg 1999). Dalej do pozycji tej odsyłam skrótem F. Liczby po skrótach oznaczają stronice. W publikacji 
przywiązywali wielką wagę ${ }^{7}$, jeden z nich Stempowski przetłumaczył na język polski, być może na użytek pani Marii ${ }^{8}$.

Listy do Dąbrowskiej i Stempowskiego, zapisy w jej dzienniku i niektóre artykuły Fiłosofowa połączone są licznymi nićmi nawiązań, z których część chciałbym zasygnalizować.

Zacząć jednak wypada od przypomnienia, kim był Fiłosofow, jaki bagaż doświadczeń wnosił w przyjaźń z polską pisarką i jej partnerem.

Urodzony w 1872 r. (2 lata młodszy od S. Stempowskiego) w Petersburgu, pochodził z rodziny szlacheckiej, której drzewo genealogiczne sięga $\mathrm{X}$ wieku. Ojciec, Władimir Fiłosofow, był na drodze do wielkiej kariery i doszedł do rangi naczelnego prokuratora wojskowego, po czym został „zdegradowany w górę”, na stanowisko członka Rady Państwowej. Przyczyną była aktywność społeczna jego małżonki, Anny Pawłowny (z domu Diagilew), która nie tylko prowadziła salon literacki, korespondowała z Iwanem Turgieniewem i Fiodorem Dostojewskim, nie tylko działała na rzecz zorganizowania Wyższych Kursów Żeńskich, ale utrzymywała też niebezpieczne znajomości z członkami organizacji Narodnaja Wola i anarchistami. Była kobietą o silnym charakterze i z jej zdaniem syn liczył się nawet jako dorosły, samodzielny mężczyzna.

Po ukończeniu świetnego Gimnazjum im. Karola Maja Dmitrij Fiłosofow studiował prawo państwowe w Petersburgu i w Heidelbergu. Mimo iż wykształcenie uniwersyteckie traktował poważnie, coraz bardziej pociągały go muzyka, malarstwo i teatr, z jednej strony pod wpływem kolegów gimnazjalnych, przyszłych wybitnych artystów: Aleksandra Benua i Konstantina Somowa, z drugiej - jego kuzyna, Siergieja Diagilewa. Wspólna wyprawa z Diagilewem w 1890 r. do Wenecji była nie tylko podróżą edukacyjną $\mathrm{w}$ świat sztuki włoskiej, ale też inicjacją homoerotyczną. 8 lat później wszedł Fiłosofow w skład skupionej wokół Diagilewa grupy Mir Iskusstwa, wydającej czasopismo o tej samej nazwie (w rodzaju Miriamowskiej „Chimery”) i książki, organizującej wystawy. W dużym skrócie można powiedzieć, że program tej grupy opierał się na kulcie piękna i indywidualności twórczej oraz na poszukiwaniu specyficznego dla Rosji „stylu narodowego". Było to najważniejsze zjawisko zapowiadające Srebrny Wiek kultury rosyjskiej. Miesięcznik „Mir Iskusstwa”, w którym Fiłosofow (wówczas dandys w stylu O. Wilde'a) prowadził dział literacki, ukazywał się do r. 1904, ale już w r. 1901 Dmitrij Władimirowicz znalazł się w kręgu oddziaływania nieco innego środowiska, skupionego wokół pisarskiego małżeństwa: Zinaidy Gippius i Dmitrija Mereżkowskiego, apostołów „wspólnej sprawy”, chrześcijańskiej wspólnoty, alternatywnej cerkwi, która przekształcić miała świadomość religijną w Rosji. Związał się z nimi i tak powstał słynny triumwirat, zwany też trio. Gippius, świadoma orientacji seksualnej Fiłosofowa, kochała go i próbowała, jeśli nie zdobyć, to przynajmniej odciągnąć od Diagilewa, co się jej w końcu udało.

tej zostały opuszczone niektóre fragmenty listów. Przytaczając jeden tego rodzaju fragment, powołuję się na rękopis ze zbiorów Muzeum Literatury.

7 Wszystkie listy Fiłosofowa skopiował S. Stempowski odręcznie, być może już po śmierci autora.

8 W liście z 2 VIII 1928 Fiłosofow nadmienia (po polsku), że pod nieobecność S. Stempowskiego „nikt nie przetłumaczy dla Pani mój list, jeżeli napiszę go po rosyjsku” (F 29). Dwa lata później (28 VIII 1930) dziękował jej za list „napisany tak pięknym językiem rosyjskim” (F 49). 
Od roku 1901 trio organizowało w Petersburgu cykliczne Spotkania Religijno-Filozoficzne, po 3 latach zakazane przez synod Cerkwi prawosławnej. Uczestnikiem ich był m.in. Marian Zdziechowski; kontakt z nim utrzymywał Fiłosofow do końca dni profesora.

Rewolucja w r. 1905 jest pierwszym doświadczeniem politycznym w życiu Dmitrija Władimirowicza. Po masakrze demonstracji przed Pałacem Zimowym Mereżkowscy i Fiłosofow zrywają spektakl w Teatrze Aleksandryjskim. Dalszy bieg wypadków pogłębia ich niechęć do samodzierżawia, ale też trwogę przed zrewoltowanym thumem, przed „nadchodzącym chamem” (Griaduszczij cham to tytuł zbioru artykułów Mereżkowskiego z r. 1906). Pod koniec roku Fiłosofow zwalnia się z pracy w Bibliotece Publicznej, po czym wyjeżdża z Gippius i Mereżkowskim na 2 lata do Paryża. Tam spotykają się z modernistami katolickimi, z Henrim Bergsonem, Anatole'em France'em, a przede wszystkim z Borisem Sawinkowem - eserowcem-terrorystą, którego postanawiają „na anioła przerobić”.

Pisane wówczas przez Fiłosofowa artykuły Wasilij Rozanow uważał za wyjątkowo słabe, twierdził, że w porównaniu z epoką „Miru Iskusstwa” autor utracił siłę wyrazu i własny styl, a wszystko dlatego, że stał się tubą Mereżkowskich.

Po powrocie do Rosji Fiłosofow wydał trzy tomy swoich artykułów i esejów: Stowa i żyzń (1909), Nieugasimaja tampada (1912) i Staroje i nowoje (1912). Jako krytyk literacki i publicysta zajmujący się drażliwymi sprawami religii budził sprzeczne opinie. Bo też i jego sądy bywały kontrowersyjne. $Z$ jednej strony, był odkrywcą talentów (to on pierwszy docenił Antona Czechowa jako dramaturga, na przekór niechętnym recenzentom torował drogę poezji Aleksandra Błoka), z drugiej - potrafił być bezwzględny, jak w artykule z 1907 r. pt. Koniec Gorkiego, w którym chciał dowieść, że polityka definitywnie zabiła artystę. Kwestia artyzmu była dla Fiłosofowa nadal ważna i właściwie nierozłączna z metafizycznym wymiarem dzieła. Dlatego, spierając się wielokrotnie z Rozanowem, doceniał nowatorstwo formalne jego prozy, otwierające drogę do zagadek ludzkiego ducha. Miał uznanie nawet dla futurystów, a w każdym razie dla Majakowskiego, choć duchowo byli mu zupełnie obcy. Punkt ciężkości literatury rosyjskiej leżał, jego zdaniem, w twórczości autora Biesów, bo nie da się zrozumieć Rosji bez lektury Dostojewskiego. O samej Rosji zaś, o jej społeczeństwie i strukturach państwa Fiłosofow wypowiadał się bardzo krytycznie.

Wybuch rewolucji lutowej r. 1917 wpędził go jednak w niepojętą depresję, podczas gdy Mereżkowscy rzucili się w wir spraw bieżących, stając po stronie Rządu Tymczasowego, w którym przez pewien okres widzieli gwaranta stworzenia nowej Rosji. Po przewrocie bolszewickim Fiłosofow zebrał się w sobie, ale wtedy już mowy nie było o działalności publicznej: ani o otwartych polemikach, ani o redagowaniu niezależnych gazet. W grudniu 1919 trójka przyjaciół wraz z sekretarzem Mereżkowskich, Władimirem Złobinem, uciekła z Petersburga. Przeszli linię frontu i znaleźli się w Polsce ${ }^{9}$. W Mińsku uchodźcami zaopiekował się generał Lucjan Żeligowski, w Wilnie spotkali się oni ze Zdziechowskim. W marcu dotarli do Warszawy, gdzie czekał na nich, poznany rok wcześniej w Petersburgu, Józef Czapski. Nawiązali kontakty z Szymonem Askenazym, Bolesławem Wie-

9 O prawdopodobnych kulisach tej ucieczki zob. P. M i t z n e r, Agent ST 1. „Zeszyty Literackie" $2010, \mathrm{nr} 4$. 
niawą-Długoszowskim, Stefanem Żeromskim i Andrzejem Strugiem. Mereżkowski rozmawiał z Józefem Piłsudskim. Pojawił się też w Warszawie Sawinkow, któremu od tej pory podlegały wszystkie oddziały rosyjskie walczące po polskiej stronie przeciw bolszewikom. Fiłosofow kierował pracami Rosyjskiego Komitetu Politycznego, a Gippius pisała do założonej przez Sawinkowa gazety „Swoboda”.

Trio, z udziałem zaś Sawinkowa przejściowo kwartet, rozumiało potrzebę oddziaływania na polską opinię publiczną, która powinna była odrzucić antyrosyjskie nastawienia i dać się przekonać, że jest szansa na stworzenie „trzeciej Rosji”: ani carskiej, ani bolszewickiej, Rosji rezygnującej z imperialnych ambicji, zapewniającej wolność nie tylko Polsce, ale też Ukrainie. Najpierw Mereżkowski, później także Fiłosofow wygłaszali utrzymane w tym duchu odczyty dla publiczności polskiej.

Po jednym z nich, w sali Warszawskiego Towarzystwa Higienicznego przy ul. Karowej, do Fiłosofowa podszedł pewien słuchacz i wręczył mu wizytówkę. Był to Stanisław Stempowski.

Gdy wojna z Rosją sowiecką zbliżała się do końca, zaraz po zawieszeniu broni niemal wszyscy działacze organizacji rosyjskich i ukraińskich zmuszeni zostali do wyjazdu z Polski. Wyjechał Sawinkow, wyjechali Mereżkowscy. Fiłosofow za zgodą Piłsudskiego pozostał, redagował gazetę „Za Swobodu!”, wizytował obozy, w których trzymano jeńców wraz z internowanymi żołnierzami sojuszniczych jednostek rosyjskich i ukraińskich. Próbował im pomagać, pisał raporty do polskich władz.

Na początku lat dwudziestych podtrzymywał jeszcze kontakt z Sawinkowem, aż do jego eskapady do Rosji (1924) i zagadkowej wolty, czyli skruchy po aresztowaniu przez Państwowy Zarząd Polityczny (Gosudarstwiennoje Politiczeskoje Uprawlenije). Wydawał i redagował gazety: „Za Swobodu!” (do 1932 r.), „Mołwę” (1932-1934), w końcu „Miecz” (od r. 1934). Był bardzo aktywnym publicystą.

Program polityczny jego gazet nie ulegał zmianom w sprawach zasadniczych: zawsze był antybolszewicki, zawsze pełen respektu dla państwa, które wielu rosyjskim emigrantom udzieliło gościny, choć nie musiało, bo rusofobia w Polsce, według Fiłosofowa, była uzasadniona latami rozbiorów. Ta myśl powracała nieraz w jego publicystyce. Prywatnie jednak, jak się zdaje, pielęgnował żal. Dąbrowska pisała w swoim dzienniku 18 I 1936:

męczy mnie strasznie swoją manią prześladowczą na temat stosunku Polski do Rosji. Wysupłuje jakieś nie mające znaczenia artykuły gazeciarskie i znęca się nad nimi. Ale gdyby nawet było tak, jak on myśli, to Polskę stosunku do Rosji uczyła krwawa i okrutna historia - uczyli Suworow, Apuchtin, Murawiew, Paskiewicz, Hurko, Sybir i szubienice. Naukę tę niełatwo wymazać. I w tym pouczaniu Fiłosofowa, jaki ma być stosunek nasz do Rosji, jest coś prowokującego, nawet dla tak obiektywnie, filozoficznie patrzącej na rzeczy tego świata istoty jak ja ${ }^{10}$.

Z jednej strony - lojalizm Fiłosofowa względem Rzeczypospolitej nie wykluczał w jego przypadku otwartego sprzeciwu wobec pewnych aspektów polityki państwa w stosunku do uchodźców i Cerkwi prawosławnej.

Z drugiej strony, akceptacja prawa Polski do samostanowienia i uznawanie aspiracji ukraińskich nie przysparzały mu zwolenników wśród rosyjskich emigrantów.

${ }^{10}$ M. D ą b r o w s k a, Dzienniki. T. 2. Wybór, wstęp i przypisy T. D r e w n o w s k i. Warszawa 1988 , s. 135 . 
Konserwatyści i monarchiści rosyjscy w jednej kwestii mieli jednak rację. Fiłosofow polonizował się (co widać też w jego listach, w których z czasem jest coraz więcej polonizmów), miał wielu znajomych i kilkoro przyjaciół spośród warszawskiej inteligencji, bywał na prywatnych rozmowach u Piłsudskiego. W roku 1934 otworzył Domik w Kołomnie ${ }^{11}$ - rosyjsko-polski klub dyskusyjny. Był już wtedy prawdopodobnie gotowy do wydania tom jego artykułów w polskim przekładzie (Marii i Józefa Czapskich oraz Stanisława i Jerzego Stempowskich), choć ostatecznie nie udało się go opublikować, a maszynopis zaginął w czasie wojny ${ }^{12}$.

Działalność Domku w Kołomnie ustała w lutym 1936 w związku z pogarszającym się stanem zdrowia gospodarza. Dwa lata później odszedł definitywnie z redakcji „Miecza”. Było z nim już tak źle, że na stałe zamieszkał w sanatorium „Wiktorówka” pod opieką dr Zofii Dobrowolskiej w Otwocku. Tam też zmarł 7 VIII 1940.

Fiłosofow prowadził bardzo ożywioną korespondencję, miał też zdecydowane poglądy na samą sztukę epistolarną. Był również jej znawcą, przygotowywał przecież kiedyś do druku listy Turgieniewa. Tworzenie listu uważał za bardzo istotny, tradycyjny rytuał, z którym nie licuje już nawet użycie wiecznego pióra, dającego możliwość pisania w każdych okolicznościach. List prywatny nie powinien być zdawkowy. Pisał do Dąbrowskiej 28 VIII 1930:

Na listy nie trzeba odpowiadać, to przesąd. Odpowiadać należy tylko na listy zawierające określone p y t a n i a, tj. na listy w interesach. Inaczej całe życie zbiegłoby na korespondowaniu. Listy należy p is a ć, kiedy przyjdzie o c ho ta, a nie odpowiadać z obowiązku. [F 49]

Ochota wynikała z potrzeby kontaktu głębszego niż rozmowa telefoniczna i odmiennego niż bezpośrednia. Traktując listy jako „coś żywego i wreszcie »literackiego «" (list z 7 V 1938, F 99), Fiłosofow nieraz poddawał je ocenie. Pisał do Stempowskiego 20 VIII 1938: „Gdy otrzymuję Pański list, przede wszystkim sprawia mi przyjemność jego »artyzm«, niezależnie od t r e ś c i” (F 112). Oceniał też swoje listy.

Można podejrzewać, że niektóre $\mathrm{z}$ nich powstawały najpierw w wersjach brulionowych, że droga do czystopisu (zresztą dość mało czytelnego) była nieprosta, tak samo jak w przypadku artykułów Fiłosofowa. Był, można powiedzieć, autorem szeregu nie wysłanych listów. Wspomina o nich w kolejnych, już wysłanych, które doszły do adresatów (Gippius, Dąbrowska) i, po latach, do nas. Z nie wysłanych ocalały chyba tylko listy Fiłosofowa do Czapskiego, może nadawca uznał je za zbyt mentorskie i napastliwe. A jednak nie zostały zniszczone.

Ogromna świadomość znaczenia korespondencji i kultura literacka Fiłosofowa

${ }^{11}$ Domik w Kołomnie przyciągał już wielokrotnie uwagę badaczy: J. Timoszewicza, I. Obłąkowskiej-Galanciak, M. Piaseckiego. Autor niniejszego artykułu podał pełny spis wykładów i listę uczestników spotkań w klubie. Zob. P. M i t z n e r, Domik w Kołomnie. Zespót i repertuar. W zb.: Noty dla edytora. Jerzemu Timoszewiczowi na urodziny 75 . Wybór, oprac. M. R a s z e w s k i, P. K ą d zi e1 a. Warszawa 2008, s. 148-151.

${ }_{12}$ Tej sprawy dotyczy list J. Stempowskiego skierowany najprawdopodobniej do W. Lednickiego (z 22 I 1932), zachowany w archiwum Dąbrowskiej i S. Stempowskiego (Bibl. Uniwersytetu Warszawskiego, sygn. 1561). W tymże archiwum znajduje się thumaczenie Stempowskiego artykułu Fiłosofowa Strach. Kilka przekładów, odrzuconych przez Fiłosofowa, znajduje się w rękach Durranta. 
każą zastanowić się, czy wymiana listów z Dąbrowską i Stempowskim nie była przypadkiem pisaną $\mathrm{w}$ odcinkach powieścią epistolarną, czymś więcej niż tylko prywatną wymianą myśli i uczuć.

Listy Fiłosofowa do Dąbrowskiej pełne są deklaracji przyjaźni, oddania, wiele w nich eleganckiej czułości: „Całuję Pani drogie ręce, a jedną z nich, prawą, ściskam z głębokim szacunkiem” (list z 28 VI 1928, F 26). Zwracał się do niej: „Przepióreczko" (więc z żartobliwą aluzją do dramatu Żeromskiego), „Ave Mario”. Dostawał od niej konfitury z truskawek. Przyznawał, że pod surową maską jest w gruncie rzeczy niesłychanie sentymentalny, i wzruszał się macierzyńską opieką autorki Nocy i dni, która sprawiała, że znów czuł się ,,małym chłopcem”, i to właśnie ośmielało go w listach do dygresji wspomnieniowych o domu rodzinnym. Dąbrowska w tych pierwszych latach znajomości postrzegała go zapewne tak, jak to zapisała w Przygodach człowieka myślacego:

Sergiusz Demidow, rosły, barczysty starszy pan po pięćdziesiątce, o bladoblond na bok sczesanych włosach, dużej wygolonej twarzy, jasnych surowych oczach pod wspaniale sklepionym czołem, ale o dziecinnie małych pulchnych ustach, stąpający trochę sztywno i ciężko, co mu nadawało niejakie podobieństwo do słonia ${ }^{13}$.

W jednym z listów znajdujemy przypomnienie początków ich przyjaźni, a więc lat 1926-1927, gdy spotykali się przy łóżku poważnie chorego wówczas Stanisława Stempowskiego, w jego mieszkaniu przy ul. Siennej: „Pamiętam też, jak nakroiła mi Pani chleb razowy, smarowała go masłem i kładła ser i przygotowywała mi kolacju” (list z 28 VIII 1928, F 42). Słowo „kolacju”, z taką właśnie końcówką, napisane zostało po polsku.

Stanisław Stempowski był swatem ich przyjaźni. Fiłosofow podziwiał jego poglądy i charakter. Tak jak pisarstwo Dąbrowskiej. Twierdził, że dla niego przede wszystkim jest autorką, a w drugiej kolejności człowiekiem, dobrym człowiekiem. Trudno powiedzieć, iż tak powstał trójkąt emocjonalny na wzór wspólnoty z Mereżkowskim i Gippius, a jednak w listach zachowały się ślady silnych napięć, niedomówień, zazdrości. Ciekawe, że pomimo (a może właśnie na skutek) dawnych doświadczeń Fiłosofow w liście do Dąbrowskiej z 24 VII 1938 zdecydowanie deklarował: „Bardzo ostrożnie odnoszę się do erotycznych komplikacji, do wszelkich amitiés amoureuses" (F 107-108).

Nie do końca wiemy, skąd się brały napięcia w tych relacjach, dość enigmatycznie sygnalizowane: „Nie chcę martwić p. Stanisława. A z drugiej strony wszelki spór z nim przekształca się w walkę o Pan ią" (list z 28 VI 1934, F 70). Fiłosofow pragnął wyraźnie dyskusji zasadniczych, ale sam na sam z Przepióreczką, lecz ponieważ nie było ku temu okazji, rozmowy we trójkę stawały się konwencjonalne. Skłonny do radykalnych sformułowań Fiłosofow stwierdzał: „Moje kontakty z Panią stają się nieszczere” (list z 28 VI 1934, F 70).

Na taką intymną szczerość mógł sobie pozwolić jedynie w liście do Dąbrowskiej. Pisząc 20 VIII 1938 do Stanisława Stempowskiego, którego w żadnym wypadku nie chciał urazić, posługiwał się aluzją, niby przypadkową dygresją:

Doskonałości n i e ma na świecie. Wszystko, co żyje, nosi skazę. „Któż bez grzechu przed

${ }_{13}$ M. D ą brow s ka, Przygody człowieka myślacego. Komentarz i przygotowanie tekstu z rękopisów E. Kor ze ni e w s ka. Przedmowa A. Kow a ls k a. Warszawa 1970, s. 189. 
Bogiem, a przed carem bez winy?" ${ }^{14}$ Wszystkim trzeba przebaczać, byle byłoby c o ś, byle by była „cebulka” (p. Bracia Karamazow ${ }^{15}$ ). [F 112]

Pawieł Ławriniec pisał niedawno o wyznawanej przez redaktora ,Za Swobodu!” „filozofii niepowodzenia"16. To prawda, że po ucieczce z Rosji Fiłosofow nie miewał już tak głębokich depresji jak wcześniej, a jeśli nawet mu się zdarzały, to nie prowadziły one do skrajnej prostracji. Pisał, działał, sytuacja zmuszała go do aktywności; nie opuszczał go jednak pesymistyczny pogląd na świat, czasami przejawiający się w zwykłym malkontenctwie. Z upodobaniem analizował relacje międzyludzkie, przekonany, że znajdzie w nich ukrytą fatalność. Szukał skazy także w przyjaźni z Dąbrowską; pisał złożony chorobą, 14 X 1936:

Okropnej nabrałem chęci, by przypomnieć Pani, że był czas, gdyśmy obcowali w przyjaźni, kiedy nie było między nami żadnej „,szklanej ściany”. Nie protestuję. Po pierwsze, granie walca Czas utracony niczemu nie służy, a po drugie - to, co było, nie traci na wartości tylko dlatego, że minęło i stało się ,utraconym”. [F 95]

Z Dziennika wiemy, że Dąbrowską czasami irytował jej rosyjski przyjaciel. Odzwierciedla to zapisany przez nią sen:

Niby to siedzę za stołem i rozmawiam z Fiłosofowem i Hiriakową ${ }^{17}$. Mówię im ze łzami w oczach: „Jakże wy możecie być takimi nacjonalistami? Patrzcież, patrzcie, to jest to samo zupełnie, co bolszewizm. Jakże wy tego nie widzicie" ${ }^{18}$.

W świetle jego listów autorka Nocy i dni jawi się jako człowiek wielkiej cierpliwości.

Ostatnie lata życia spędzał Fiłosofow w chorobie i przymusowej bezczynności. Czuł się opuszczony. Wydawało mu się, że przyjaciółka uporczywie go unika. „Jest już za późno" - pisał do niej 22 VIII 1939, na tydzień przed wybuchem wojny: za późno na poważne rozmowy i coś się w przyjaźni popsuło; był traktowany jak zdziecinniały starzec, ale przecież zachował dawne zasady i jego miłość - jak kontynuował w liście - nadal ,jest, niestety, wymagająca. Nie lubię bukietów, kadzideł, w ogóle, tandety". Dalej przeplatają się słowa wdzięczności (np. za Noce $i$ dnie) z bezwzględnymi stwierdzeniami w rodzaju: „Pani utraciła s i e bi e...” (F 126).

W relacjach ze Stanisławem Stempowskim takiego kryzysu nie było. W listach do niego i do Dąbrowskiej wielokrotnie dawał dowody czci i szacunku, jakimi go darzył. Zdaniem Fiłosofowa, łączyło ich wiele: od formującego niegdyś ich osobowości przekonania o konieczności pokuty szlacheckiej wobec ludu, do podobnego syndromu chorobowego, który uważał za psychosomatyczną reakcję na zło świata. Rozumieli się doskonale, choć różnili się w kwestiach światopoglądowych.

${ }^{14}$ Rosyjskie przysłowie.

${ }^{15}$ Chodzi o ks. VII, rozdz. 3 powieści F. D o s t o j e w s k i e g o Bracia Karamazow. Monolog Gruszy - przypowieść o potępionej babie, którą anioł stara się wyciągnąć z ognistego jeziora za pomocą cebulki, podarowanej przez nią kiedyś żebraczce. Do cebulki próbują się jednak doczepić inni grzesznicy, baba ich odpędza, cebulka się urywa i baba na powrót wpada do piekła.

${ }_{16}$ P. L a w r i n i e c, Motiw nieuspiecha w pozdniej publicystikie D. W. Fiłosofowa. „Literatūra” (Vilnius) 2006, nr 2.

17 W Dziennikach Dąbrowskiej to nazwisko jest pisane przez „Ch”, przyjmuję jednak pisownię przez „H”, zgodnie z zasadą stosowaną w korespondencji z Polakami przez samą Hiriakową.

${ }^{18}$ D ą brow s k a, Dzienniki, s. 184. 
Fiłosofow uważał np. ideę spółdzielczości, do której tak był przywiązany Stempowski, za przeżytek, za strategię nieskuteczną w czasach rewolucji: bolszewickich i faszystowskich. Formułował zresztą fatalistyczny pogląd, że cały świat musi przejść przez piekło takich czy innych rewolucji (list z 7 V 1938, F 99). Do poważnej wymiany argumentów w kwestii spółdzielczości doszło też w związku $\mathrm{z}$ artykułem Dąbrowskiej Rozmyślanie na czasie ${ }^{19}$. Zawarte tam wyznanie wiary w spółdzielczość Fiłosofow uznał za zupełnie nie na czasie i pięknoduchowskie, w dodatku ideę tę uważał za sprofanowaną w praktyce sowieckich kołchozów. Pisał w liście z 18-20 VIII 1935, że lepiej uważać, iż, ,jak powiada prorok Izajasz, »lew i owca pospołu mieszkać będą, a miecze zostaną przekute na lemiesze $«{ }^{20}$, niż w i e r z y ć w komunistyczne kooperatywy" (F 90).

Stąd wynika druga kwestia sporna: Fiłosofow był człowiekiem wierzącym, religijnym i wyraźnie dystansował się od wolnomyślicielstwa i wolnomularskich poglądów przyjaciela. I jest to chyba dowodem na to, że do masonerii nie należał, choć w jego otoczeniu przedstawicieli tego zakonu było wielu, dość wspomnieć Sawinkowa. Fiłosofow pisał w liście adresowanym do Dąbrowskiej, ale wyraźnie skierowanym do Stempowskiego:

Uważam, iż n a j c i ę ż s z y m g r z e c h e m XIX wieku (,postępu”, „,cywilizacji” i innych fetyszy, w tym też droits de l'homme!) jest to, że pozbawił on człowieka tego, co najcenniejsze: w olno śc i relig i n e j, kojarząc religię z kościołem. Jeśli uznaje się wartości religijne, człowiek jawi się (w oczach ludzi „oświeconych”) jako obskurant, reakcjonista i klerykał. „Klerykalizm” jest mi równie wstrętny jak tandeta droits de l'homme ${ }^{21}$.

W listach sygnalizuje swoje myślenie religijne, wskazując na najważniejsze dla niego u schyłku życia lektury: Biblię i Pascala, ale zwraca też uwagę Dąbrowskiej na to, że nie docenia ona religijnego wymiaru człowieka i nie podejmuje nawet dyskusji wokół tego problemu. Dlatego z satysfakcją obserwuje i donosi Stempowskiemu w liście z 12 VIII 1930, iż w sanatorium w Jaworzu pani Maria „codziennie spiera się z księdzem Pudrem ${ }^{22}$ na tematy teologiczne” (F 46).

Postacią drugiego planu w tej korespondencji jest Jerzy Stempowski, chociaż był on w bardzo bliskich stosunkach z Fiłosofowem, należał do ścisłego „zarządu” Domku w Kołomnie, wygłaszał tam referaty. To, co między nimi wytwarzało dystans, to, jak twierdził Dmitrij Władimirowicz, różnice „raczej psychologiczne niż ideowe". Z powodu tych różnic, choć w istocie rzeczy byli zgodni, odmiennie odbierali rzeczywistość, „bolało ich co innego”.

Czasy są wyjątkowe i trudno pojąć, jak reagować i co robić. Myślę, że Jerzyk (którego szczerze lubię, i to nie frazes!) bagatelizuje głębię tego ideowego, moralnego i mentalnego kryzysu, który, być może, nawet wbrew swojej woli, przeżywa teraz ludzkość. Wszystko, co nowe, rodzi się w cierpieniach i brudzie. [list z 22 VII 1935, F 79]

Pewien epizod rzuca też światło na codzienność ich kontaktów. Fiłosofow opisuje spotkanie z Jerzym Stempowskim na pogrzebie Szymona Askenazego:

19 M. D ą b row s k a, Rozmyślanie na czasie. „Wiadomości Literackie” 1935, nr 11.

${ }_{20}$ Połączenie dwóch cytatów z Proroctwa Izajasza (Iz 11, 6; 2, 4). Tu w przekładzie J. W u j k a.

${ }^{21}$ Korespondencja S. Stempowskiego i M. Dąbrowskiej z D. Fiłosofowem z lat 1926-1939.

22 Tadeusz P u d e r (1908-1945) - ksiądz katolicki, pochodzenia żydowskiego, związany ze środowiskiem Lasek. 
Powiedział, że chciałby się ze mną spotkać. Odpowiedziałem: „Dziś mamy wtorek. Niech pan wybierze dzień: środę, czwartek, piątek, sobotę, niedzielę - to się spotkamy". Okazało się, że nie może zdecydować, obiecał, że zadzwoni. Do dziś [pisane w sobotę - P. M.] czekam na telefon. I ten człowiek pisze przeciw „czynom”! To jakby głuchy pisał przeciwko muzyce. Proszę mi wybaczyć złośliwość. [list z 6 VII 1935, F 78]

Drobiazg ten sygnalizuje, że istniały jednak pewne głębokie różnice charakterów i poglądów. Fiłosofow nieraz zdecydowanie sprzeciwiał się wymowie niektórych tekstów Jerzego Stempowskiego. Niewątpliwie Fiłosofow wypominając, że: „pisze [on] przeciw »czynom«", miał na myśli jego esej o Malraux, który $n b$. był przeróbką referatu wygłoszonego w Domku w Kołomnie. Tekst André Malraux $i$ mit czynu wszedł do książki Literatura $w$ okresie wielkiej przebudowy, która Fiłosofowa „zasmuciła i uraziła”. W liście do Dąbrowskiej z 6 VII 1935 narzekał na styl autora, ,elegancką causerie bez najmniejszej odpowiedzialności i woli, jego program maksymalny: l'art pour art - zasmuca mnie głęboko i powiem nawet oburza" (F 77). Trudno też zapewne było mu zaakceptować esej ${ }^{23}$ - pamflet na Piłsudskiego, którego rosyjski emigrant uważał przecież za jedną z największych postaci historii Polski24 i z którym, jako jego poufny doradca, czuł się blisko związany. Pisał 6 VII 1935 do Dąbrowskiej:

Śmierć Piłsudskiego zrobiła na mnie ogromne wrażenie. Bardzo poruszyła mnie także o s o b i ś c i e i uzmysłowiła, że w wymiarze „społecznym” i ,politycznym” moje życie w Polsce dobiegło końca. [F 77]

Zdecydowanie częściej niż Jerzy Stempowski pojawia się w tej korespondencji rodzeństwo Czapskich ${ }^{25}$. Z Józefem spotkał się Fiłosofow w Petersburgu w grudniu 1918, z Marią - już w Polsce. Oboje, bardzo mu oddani, stali się w ostatnich latach życia redaktora obiektem jego wysiłków edukacyjnych. Był zdania, że stanowią „bardzo dobry materiał” (list z 12 IX 1930, F 51), a ich otwartość, prostoduszność uważał za cechy raczej pozytywne. Walczył przy tym o rozwój intelektualny Czapskiego i chciał hartować jego charakter („galaretę"). Ciekawe, że identyczny zarzut stawiały ćwierć wieku wcześniej Fiłosofowowi kobiety jego życia: matka i Gippius. W pisarstwie Czapskiej tępił on sentymentalizm, powierzchowność sądów, brak precyzji.

Nieumiejętność czytania (a nawet nieznajomość) źródeł wytknął zresztą też polskim historykom literatury, badającym biografię Mickiewicza, przede wszystkim samemu Juliuszowi Kleinerowi ${ }^{26}$, za co zaatakowany został przez Manfreda Kridla ${ }^{27}$. Widział on w Fiłosofowie typowego rosyjskiego inteligenta, pouczającego Polaków, przeciwstawiającego kulturę Rosji początku XIX w. „barbarii polskiej”, która wydała Mickiewicza. W obronie Fiłosofowa stanęła wtedy Dą-

23 J. S te m pow ski, Pan Jowialski i jego spadkobiercy. Rzecz o perspektywach śmiechu szlacheckiego. Szkic literacki. Warszawa [1931].

${ }^{24}$ D. Fiło s o fo w: Smiert' wożdia. „Miecz” 1935, nr 20; Wielikije ludi i my. Jw., nry 2628,30 .

${ }^{25}$ Zob. P. Mitzner, Fiłosofow i Czapscy. „Zeszyty Literackie” 2009, nr 107.

${ }^{26}$ D. F ił o s o fo w, Mickiewicz w Odessie i na Krymie. Na marginesie dzieła prof. Kleinera o Mickiewiczu. „Przegląd Współczesny” 1934, nr 142 (luty).

${ }_{27}$ M. K ri d l, Niepowołany mentor. „Wiadomości Literackie” 1934, nr 11. Spór ten zreferował J. Kr z y ż a n o w s k i w artykule Na manowcach „,Drogi do Rosji”. Fiłosofow versus Kleiner („Ruch Literacki” 1934, nr 3). Uzupełnienie tegoż autora: Jeszcze o „,Drodze do Rosji” (jw., nr 5). 
browska ${ }^{28}$. Protestowała przeciwko przypisywaniu mu antypolskich pobudek. Zwracała uwagę, iż jego zarzuty wobec polskich badaczy wcale nie są błahe. W końcu rozprawiała się z określeniem: ,cudzoziemiec, zwłaszcza tak zainteresowany w odbudowie ówczesnej Rosji”, zaznaczała, że Fiłosofow „był w niezgodzie i walce z ówczesną Rosją, jej ustrojem”, a od przyjazdu do Polski znosił „twardy żywot emigranta", przy tym był otwarty na sprawy polskie, studiował naszą literaturę i historię. Wielokrotnie zapraszano go do współpracy z polską prasą, on jednak podkreślał, że nie chce być „intruzem, niepowołanym do wtrącania się w nieswoje rzeczy" ${ }^{29}$. W końcu dał się namówić; niestety, jak pisała Dąbrowska, jego wstępne obawy okazały się słuszne.

Fiłosofow bardzo przeżył atak Kridla. Kwestia rzetelności w badaniach naukowych, w publicystyce była dla niego zawsze niezmiernie istotna. Kiedy więc skarżył się na roztrzepanie i nierzetelność w sferze faktografii w tekstach Czapskiej, poniekąd nawiązywał do tamtej sprawy.

Dąbrowska i Stempowski poznali Czapskich w r. 1927, właśnie przez Fiłosofowa, a później, jak wynika z korespondencji, włączyli się, szczególnie zaś „,pan Stanisław" do intensywnej pracy nad intelektem Czapskiej.

Dąbrowska i Stanisław Stempowski za pośrednictwem Fiłosofowa zetknęli się także bezpośrednio z niektórymi przedstawicielami rosyjskiej emigracji z jego najbliższego otoczenia, o wielu dowiedzieli się z listów, a pewnie też z rozmów. W korespondencji pojawiają się nazwiska młodszych kolegów redakcyjnych Fiłosofowa: Władimira Branda ${ }^{30}$ i Antona Dąbrowskiego ${ }^{31}$. Najczęściej jednak Jewgenii Weber-Hiriakowej ${ }^{32}$, występującej tu jako Żenia lub Jessica ${ }^{33}$.

Przede wszystkim zaś z zespołu listów Fiłosofowa wyłania się jego autoportret. Oto człowiek nieustannie chorujący ${ }^{34}$. Zapisuje, nieraz bardzo szczegółowe, obserwacje pacjenta sanatorium, najpierw w Jaworzu ${ }^{35}$, później w Otwocku. Tam, siłą rzeczy, jest wśród ludzi, czasem dość pospolitych, ale znajduje pewną przyjemność w przyglądaniu się ich zachowaniom, z niektórymi zawiera bliższą znajomość, po ludzku przywyka do nich bardzo.

${ }_{28}$ M. D ą brow ska, O dobre obyczaje polemiczne. „Wiadomości Literackie” 1934, nr 13. Pod artykułem znajduje się postscriptum W. L e d n i cki e g o.

29 Ibidem.

${ }^{30}$ Władimir B r a n d (1892-1942) - poeta, dziennikarz, działacz organizacji Narodno-Trudowoj Sojuz. Zginął organizując antyhitlerowski ruch oporu w Smoleńsku, prawdopodobnie zlikwidowany przez agenturę NKWD.

${ }_{31}$ Anton D ą b r o w s k i (1889-1938) - Polak z pochodzenia, rosyjski prozaik i dziennikarz.

32 Jewgenia We be r-Hiriak ow a (1895-1939) - była publicystką, krytykiem literackim i teatralnym. Drukowała artykuły w gazetach redagowanych przez Fiłosofowa, a także w prasie polskiej („,Verbum”, „Pion”, „Marchołt”), była jego najbliższą współpracowniczką i kimś w rodzaju sekretarki. Udzielała Dąbrowskiej korepetycji z języka rosyjskiego i była nią zafascynowana. Autor niniejszego szkicu zamierza następny poświęcić tej niezmiernie ważnej postaci z kręgu Fiłosofowa.

33 To oczywista aluzja do Kupca weneckiego Szekspira. Jewgenia tak jak Jessica, córka Shylocka, uciekła $\mathrm{z}$ domu $\mathrm{z}$ chrześcijaninem i zmieniła wiarę.

${ }^{34}$ Fiłosofow był rzeczywiście słabego zdrowia i temat choroby przewija się w jego zapiskach z całego życia: $w$ dzienniku z okresu petersburskiego, w listach do przyjaciół.

${ }^{35}$ Ciekawe jest zestawienie entuzjastycznej opinii Dąbrowskiej o Jaworzu z satyrycznymi uwagami Fiłosofowa, zawartymi w jego listach. Zob. M. D. [M. D ą b r o w s k a], Jaworze. „Tygodnik Ilustrowany" 1927, nr 45. Przedruk w: M. D ą b r o w s k a, Pisma rozproszone. Red., przypisy E. Korzeni ew ska. T. 1. Kraków 1964, s. 359-365. 
Na co dzień Fiłosofow był człowiekiem samotnym, cierpiącym na „chandry”, które pewnie dałoby się zdiagnozować jako depresję. Nie mógł się z nich wydobyć, zdawał sobie $\mathrm{z}$ nich sprawę (a niekiedy nawet obśmiewał), unikał ludzi z obawy, iż nerwy odmówią mu posłuszeństwa, iż ujawni się jego wrodzona złośliwość. Czuł, że w odosobnieniu traci umiejętność rozmowy, a słowa zdają mu się puste. Stany depresyjne nawiedzały go nie tylko w ostatnich latach życia, gdy przebywał w Otwocku, ale nawet wtedy, gdy jeszcze redagował gazety, pisał artykuły.

Fiłosofow wierzył w sens swojej pracy, zwłaszcza gdy w jego kręgu, w składzie redakcji, w emigracyjnym środowisku literackim pojawiali się młodzi ludzie. Wtedy działał na przekór polemistom i przeciwnikom politycznym, pokonując kryzysy finansowe - o tym wszystkim systematycznie informował Dąbrowską i Stanisława Stempowskiego. Sam też bywał w dramatycznej sytuacji materialnej i to oni właśnie ratowali go pożyczkami rzędu 20 złotych. Przed nędzą chroniła go również, jak pisał, pomoc od przyjaciela fabrykanta Mojżesza Gomberga, który niekiedy wypłacał mu coś w rodzaju niewielkiego stypendium.

Wspominał jednak w listach otwarcie także o swoich wątpliwościach, czasami zasadniczych, np. o niechęci do Rosjan („Rosjan mam już dość, jak Dziadek [tj. Józef Piłsudski] Polaków", list z 6 VII 1928, F 28) czy na temat wydawania gazety, w dodatku, emigracyjnej:

J e stem wewnętrzni e zm ę c zony. Trudno żyć na emigracji, mając moje wymagania. Przywykłem do ,arystokracji i wyższej matematyki”, a tu trzeba „chłopów” uczyć tabliczki mnożenia. [list z 2 VIII 1928, F 30]

Konstatował, że w roli, jaką przyszło mu grać, czuje się jak „rachityczny słoń w brudnej klatce" (list z 6 VII 1928, F 27).

$\mathrm{Z}$ pewnego rodzaju zawiścią stwierdzał Fiłosofow, iż w przeciwieństwie do niego Stempowski może ,ignorować kulisy teatru prasowego, gdzie powietrze jest zepsute, a kiedy zrobi się przeciąg - wszystkie rękopisy lecą z wiatrem" (list z 25 VIII 1933, F 63).

Próby zdefiniowania siebie, podsumowania życia w listach do polskich przyjaciół nieraz były ilustrowane fragmentami wspomnień z okresu dzieciństwa i młodości. Zresztą takimi fragmentami posługiwał się Fiłosofow często też w publicystyce i choć pamiętników, we właściwym tego słowa znaczeniu, nie prowadził, można z tych urywków odtworzyć przynajmniej niektóre okresy jego życia. Przed systematycznym pisaniem, do którego namawiał go Stanisław Stempowski ${ }^{36}$, powstrzymywało go nieziszczalne pragnienie, żeby wspominać „nie tylko to, co się pamięta, ale wspominać to, co się zapomniało albo zdaje się niejasne" (list z 8 VIII 1938, F 119).

Ciekawe, w jaki sposób w listach do Dąbrowskiej pojawia się postać Gippius. Fiłosofow odczuwa potrzebę cytowania jej wierszy, lecz z pewnym wahaniem, nie ujawniając autorki albo wymieniając jej nazwisko dopiero po jakimś czasie. Jednocześnie, w liście do Gippius chwali się swoją przyjaźnią z polską „znaną pisarką" ${ }^{37}$.

${ }^{36}$ Skutkiem tego był powrót do pisania (nieregularnie) dziennika, który, do dziś nie opublikowany, znajduje się w posiadaniu Durranta.

${ }^{37}$ D. F i ł o s o f o w, list do Z. Gippius, z 1 V 1934. W: T. P a c h m u s s, Stranicy iz proszłowo. 
Podsumowania pobytu w Polsce nie były łatwe, często sprowadzały się do wymieniania nazwisk zmarłych przyjaciół i współpracowników: Boris Sawinkow, Michaił Arcybaszew, Wiktor Portugałow, Danił Pasmanik, Anton Dąbrowski. Na kilka lat przed śmiercią Fiłosofow zabrał się za porządkowanie archiwum. Najbardziej intymne listy i zapiski polecił po swoim pogrzebie spalić (tak też się stało), część papierów odesłał do siostry, mieszkającej we Francji. Zamierzał także zwrócić niektóre listy nadawcom (czego ostatecznie nie zrobił): „Nie chciałbym, żeby w ważne dla mnie listy ktoś zawijał śledzie". Tak powoli zbierał się do odejścia, stwierdzając z żalem, iż „nie udoskonalono do tej pory »techniki« umierania” (list z 24 VIII 1930, F 48).

Fiłosofow, szkicując autoportret, bywał wobec siebie krytyczny. Wiedział, że jest mizantropem i malkontentem. Na co jednak pozwalał sobie, to nie zawsze było dozwolone postronnym. Dlatego Rosjanin bronił się, gdy Dąbrowska zarzucała $\mathrm{mu}$, iż w gruncie rzeczy nie lubi ludzi. Podobało mu się natomiast, kiedy Stempowski nazwał go ,rycerzem przegranej sprawy” (list z 25 VIII 1928, F 39), a pisząc o swoim wystąpieniu na zebraniu PEN Clubu, Fiłosofow stwierdził, że czuł się Komandorem z Don Juana. „I mój Boże, jak współcześni don juani z »Wiadomości Literackich« i MSZ nie potrafią stać mocno na ziemi” (list z 14 VII 1930, F 43).

Tu dodać należy, że „Wiadomości Literackie”, które kilkakrotnie drukowały wypowiedzi Fiłosofowa, były dla niego wyrazistym przykładem kulturowej dekadencji i politycznej krótkowzroczności. Szczególnie zirytował go specjalny numer sowiecki „Wiadomości Literackich” (1933, nr 47) i publikacja artykułów Karola Radka ${ }^{38}$, co zbiegło się z zaostrzeniem interwencji cenzury wobec "Mołwy”. W związku z dyplomatycznym zbliżeniem z Moskwą zdejmowane były wszystkie ostrzejsze teksty antysowieckie. Tymczasem „Wiadomości Literackie” bezkrytycznie propagowały literaturę Kraju Rad. Fiłosofow miał na ich temat wyrobione zdanie. Dlatego niedługo przed wojną ze zdziwieniem konstatował nowy, patriotyczny image tygodnika. Nie sądził chyba jednak, że jest to głęboka zmiana.

Nadal zapewne uważał, iż „niewielka powódź wystarczy, by kawiarnia Ziemiańska i »Wiadomości Literackie«, (Mortkowicz y compris) popłynęli jak zerwana słomiana strzecha" (list z 14 VII 1930, F 43). Starał się nie ingerować w konflikty, które antagonizowały jego polskich przyjaciół - pisał o tym w liście do Mariana Zdziechowskiego ${ }^{39}$ - ale, jak wiadomo, bywał porywczy i opinie podobne do zacytowanej ukształtowały pogląd, że oceniał sprawy polskie z ironią, $\mathrm{z}$, petersburskiego punktu widzenia” 40 .

Fiłosofow od początku lat trzydziestych $w$ rozmowach, odnotowanych w dziennikach Dąbrowskiej, dziwił się, że Polacy w większości nie doceniają powagi sytuacji międzynarodowej i nie szanują niepodległości. Powinni „pomagać pań-

Pieriepiska Z. N. Gippius i D. W. Fiłosofowa i blizkich k nim o „Gtawnom”. W zb.: Pamiatniki kultury. Nowyje otkrytija: piśmiennost', iskusstwo, archeołogija. Moskwa 1998, s. 96.

${ }^{38}$ K. R a d e k: Kultura rodzącego się socjalizmu. „Wiadomości Literackie” 1933, nr 47; Polska powieść rewolucyjna. Jw., 1934, $\mathrm{nr} 35$.

${ }^{39}$ D. F i ł o s o f o w, list do M. Zdziechowskiego, z 7 I 1931. W: P. Ł a w r i n i e c, Listy Dymitra Fiłosofowa do Mariana Zdziechowskiego. Przeł. H. D u b y k. „Zeszyty Historyczne” 2008, z. 165 , s. 190 .

40 J. I w a s z k i e w i c z, Petersburg. W: Podróże. T. 2. Warszawa 1981, s. 260. 
stwu", jak pisał w jednym z listów, gdy tymczasem skupieni są na własnym Schadenfreude (list z 6 VII 1935, F 77). „Macie dom - mówił - teraz zacznijcie w nim żyć” ${ }^{41}$. Właśnie takie poglądy ,państwowca” wypowiada w dyskusji Demidow, bohater Przygód czlowieka myślacego ${ }^{42}$.

Fiłosofow uważał, że Polska odrodzona powinna zapomnieć o romantyzmie, lecz uprawiać ogródek, uczyć się od Holendrów, Szwajcarów i Duńczyków i pracować, jak pisał, nad unowocześnieniem motyki (list z 14 VII 1930, F 44). Tego trzymał się właściwie przez cały czas emigracji, a miała ta myśl także swój rewers: Rosjanie powinni wyjść z marazmu duchowego i przejąć się duchem polskiego romantyzmu ${ }^{43}$.

Na tydzień przed wybuchem wojny, gdy przerażona Dąbrowska nie mogła sobie znaleźć miejsca, Fiłosofow zalecał jej opanowanie: „O d s i e b i e nie uciekniesz” (list z 22 VIII 1939, F 123). „Od siebie”, czyli od Marii Dąbrowskiej.

Pierwsza wypowiedź Fiłosofowa o Nocach $i$ dniach znajduje się w liście do pisarki z kwietnia 1932, dwa miesiące po wydaniu drugiego tomu powieści: „Pani przykłada się do czegoś, co stoi jakby ponad Panią”. Autor snuje rozważania o sensie męki twórczej, o znaczeniu tej książki dla polskich czytelników, a także dla niego samego:

Uczciwie i szczerze otworzyłem się na Polskę, za co wiele wycierpiałem, tak ze strony Polaków ${ }^{44}$ (obłudny Moskal!), jak i ze strony Rosjan (zaprzedał się Polakom!). Dzięki Pani powieści zrozumiałem, za co kocham Polskę i jaką Polskę kocham. Pokazała mi cierpienia d a w n e j Polski i jej prawo do miejsca pod słońcem. Za to błogosławię Panią. [list z 25 IV 1932, F 56]

Po wyjściu tomu 3 (Miłość) Fiłosofow uważnie śledził ukazujące się w prasie recenzje, wysyłał je autorce, komentował. Pisał:

Zapewne ma Pani rację - ganią także „nie za to”, jak i „chwalą”. Z punktu widzenia „wydawcy" dobrze, że Pani nie zaczęto besztać. Nadmiar pochwał też nie zawsze jest dobry. Zwłaszcza $\mathrm{m} \nmid$ o d z i e ż nie lubi, gdy chwalą. Historia literatury uczy nas, że sąd współczesnych nie ma żadnego znaczenia. Współcześni są in te re s o w n i: patrzą na wszystko z punktu widzenia b i e ż ą c y c h spraw. [list z 19 VIII 1933, F 61]

W trakcie lektury tego tomu Fiłosofow w liście z 30 VIII 1933 zapisał na gorąco wrażenia z lektury:

Uważam, że niedoszła wizyta Toliboskiego, przyjazd Barbary do Serbinowa i z wła s zc z a opis wesela Felicji (prawda, zapomniałem o Januszu - Celinie!) - wszystko to są rzeczy klasy najwyższej. Rzeźbione „w kamieniu”, żeby ludzie nie zapomnieli. I to, że odbywa się to w chwili „,przypływu” rewolucji, kiedy lada chwila fale zmiotą Serbinów, a pani Barbara ,j a k g d y b y" tego nie dostrzega - świadczy o wielkim mistrzostwie. Coraz bardziej i bardziej występuje tło tego eposu: ,afirmacja życia” i to afirmacja p o z y tywna. (Rozmowa Barbary z Ceglarskim!).

${ }^{41}$ Cyt. za: D ą b r o w s k a, Dzienniki, t. 1, s. 240 (9 III 1928). „Żyć” - da się przethumaczyć, oczywiście, także (może właściwiej) jako: 'mieszkać'.

${ }^{42}$ D ą b row s k a, Przygody człowieka myślacego, s. 346-347.

${ }_{43}$ Rozmowę na ten temat relacjonuje Dą brow s k a w Dziennikach w zapisie z 17 I 1928 (t. 1, s. 227).

${ }^{44}$ W grudniu 1934 S. Stempowski zaangażował się osobiście w obronę czci Fiłosofowa. Udał się w tym celu na rozmowę z R. Raczyńskim, publicznie rzucającym potwarze (zob. D ą b r o w s k a, Dzienniki, t. 2, s. 83, 85). 
Dalej Fiłosofow szuka argumentów na obronę powolnej narracji w powieści, „dłużyzn”, z których powodu bywa krytykowana.

Gdyby nie było tych „dłużyzn”, tego spokojnego płynięcia wielkiej rzeki, wiele rzeczy utraciłoby swój wewnętrzny sens. Krótkie spięcie - Janusz-Celina - przekształciłoby się w „modną” nowelkę, w temat dla pani Melcer lub Krzywickiej.

W tym samym liście Fiłosofow próbuje umieścić powieść Dąbrowskiej na szerszym tle historycznoliterackim:

Ach, i jeszcze jeden ważny temat: zagadnienie „tradycji”. U Francuzów, najbardziej tradycyjny ch pisarzy, tradycje ciągną się od XVII wieku. U nas od Puszkina i Gogola. U was usiłowano wywodzić tradycję od wieszczów, ale, jak się zdaje, nie bardzo się to udało. Tradycja idzie od Orzeszkowej, Prusa, Żeromskiego. Tj. dopiero się rozpoczęła. Zapewne odegrały tu rolę i wpływy rosyjskie (Turgieniew, Tołstoj) i zachodnie: Dickensa i George Sand na Orzeszkową, Flauberta - na Panią. Tym niemniej jednak właśnie w twórczości Orzeszkowej, Prusa i Żeromskiego zarysowała się, a właściwie ufundowana została istotna polsko-słowiańska tradycja, którą Pani wzięła odważnie w swe ręce. Dlatego Pani zostanie w polskiej literaturze, dlatego Pani nie jest moderne w oczach filarów „Wiadomości Literackich”. Oni bowiem pracują dla dnia dzisiejszego, niezrozumiałą jest dla nich mozolna praca wykuwania w granicie. Dlatego efektowniej jest sklecić cokolwiek ,z kartonu”, oświecić „reflektorem” i dać akompaniament z murzyńskiej muzyki. Nie jestem wcale przeciwnikiem kartonu z reflektorami. Ale nie mogę znieść, kiedy karton wyobraża sobie, że jest granitem ${ }^{45}$.

Fiłosofow był wnikliwym czytelnikiem Nocy $i$ dni, i to nie tylko w druku, od pewnego momentu dostawał do lektury także maszynopis. Jako jeden z pierwszych otrzymywał egzemplarze autorskie kolejnych tomów z dedykacjami.

Dość obszerny list z 3 X 1934 zawiera błyskawiczną reakcję na ostatni tom powieści, a właściwie na dedykację, opatrzoną mottem z Eklezjasty - rozpoczynającym się słowami: „Marność nad marnościami, i wszystko marność” (Koh 1,2) ${ }^{46}$. Fiłosofow posłużył się wieloma argumentami przeciw użyciu tego właśnie cytatu - jakby rzecz była drukowana. Przede wszystkim uważał go za zbyt obiegowy. Twierdził też, że stosowny jest do klimatu połowy lat trzydziestych, powieść jednak jest „historyczna” i do atmosfery roku 1914 słowa te absolutnie nie pasują. Kwestia przełomowego znaczenia roku 1914 i w świadomości europejskiej, i w powieści Dąbrowskiej była dla Fiłosofowa na tyle istotna, że powrócił do niej rok później w jednym ze swoich artykułów. Rysując w skrócie atmosferę świata Nocy $i d n i$, „epoki rozczarowań, szarej codzienności” i życia po klęsce, silny nacisk kładł w nim na pojawienie się Sebastiana, a wraz z nim tego „burzliwego potoku”, dzięki któremu doszło do odrodzenia Polski ${ }^{47}$. Chodzi rzecz jasna o legiony i Piłsudskiego. Sebastian rzuca szaleńcze i bezkompromisowe: „nie pozwalam” (pisane przez Fiłosofowa po polsku), przełamując marazm rzeczywistości. Dodać można, że według rosyjskiego krytyka był to romantyczny akcent postawiony w stosownym czasie i miejscu. Zanim do tego doszło, Fiłosofow odczytywał Noce $i$ dnie jako powieść antyromantyczną, oczyszczającą z toksyn, które nagromadziły się w duszy polskiej w okresie zaborów, powieść poświęconą „,szarym ludziom”, którzy po

45 D. F ił o s o fo w, list do M. Dąbrowskiej, z 30 VIII 1933. Przeł. S. S t e m p o w s ki (Muzeum Literatury).

${ }^{46}$ Pełny cytat w przekładzie J. Wujka umieszczony w dedykacji, zob. Dąbrowska, Dzienniki, t. 2, s. 55.

${ }^{47}$ D. F ił o s o f o w, ,Nie pozwaliam!” Z cyklu,,Woskrisnyje biesiedy”. „Mołwa” 1933, nr 213. 
prostu ,żyli, cierpieli, kochali, umierali”, ale to dzięki nim Polska dożyła niepodległości, ludziom, nad których losem autorka pochyla się z miłością i przebaczeniem, a „umie przebaczać, bo rozumie" ${ }^{48}$. Nie oznacza to, że Dąbrowska w jakiś sposób spełniała oczekiwania Fiłosofowa wobec literatury, że realizowała jego program literacki. Owszem, mieściła się w nim, ale był on wewnętrznie zróżnicowany. Zawierał: realizm i intuicjonizm, kulturę i przełamywanie tabu, dobroć i okrucieństwo, indywidualizm i prawdę życia społecznego - o tym wszystkim wspominał zresztą Fiłosofow w listach do pisarki i to jest czytelne w jego publicystyce.

To, co może wydawać się labilnością jego poglądów, wynikało z założenia, że literatura i sztuka w pewnym sensie powinny odpowiadać na potrzeby czasu, że mają do spełnienia misję społeczną (stąd np. szacunek Rosjanina dla kampanii Boya przeciw „brązownictwu”), choć zarazem powinny się mierzyć z tym, co „wieczne”. Oczywiście, nie każdy pisarz, który ma wrażenie, iż dotyka spraw wiecznych, pozostaje w żywym obiegu kultury. Dlatego do minionych sław Fiłosofow zaliczał np. Victora Hugo, Anatole'a France'a i wreszcie Stanisława Przybyszewskiego, który, co nieraz podkreślał, miał zdecydowanie zły wpływ na literaturę, także rosyjską.

Muszę jeszcze wrócić do kwestii użytego w dedykacji Dąbrowskiej cytatu z Eklezjasty. Fiłosofow był zdania, że jest on obcy postaciom powieści, które tego rodzaju pesymizm świadomie odrzuciły. Pojawienie się tego „motta”, jak pisał Fiłosofow, tłumaczył sobie stanem ducha autorki, jej zmęczeniem i niepotrzebną próbą ujawnienia własnego poglądu na świat, gdy w poetyce swojej „powieści klasycystycznej, nie romantycznej" umiała się ukrywać za plecami bohaterów (list z 10 IX 1934, F 71-73). Dąbrowska uważała, że reakcja Fiłosofowa na cytat z Eklezjasty jest nieadekwatna, że jednak w pewnym sensie oddaje on mentalność niektórych postaci ${ }^{49}$. Aby uspokoić przyjaciela, wręczyła mu wszakże egzemplarz $\mathrm{z}$ inną dedykacją.

Wątek Nocy $i$ dni w korespondencji zamyka zdanie z listu Rosjanina do Dąbrowskiej z 14 X 1936, w którym dziękuje on autorce za Noce $i$ dnie, pisząc: „stanowily [one] epokę w mojej biografii duchowej” (list z 14 X 1936, F 95).

Obiecywał i samej autorce, i czytelnikom swoich artykułów, że przygotuje większe studium o powieści. Pozostał nie datowany rękopis, kilka stronic, początek zarzuconego tekstu. Jest to zaledwie wstępny zarys tła estetycznego i teoretycznoliterackiego, na którym miała być analizowana powieść Dąbrowskiej.

W tym samym archiwum, w którym zachował się ów fragment, znajduje się też nie drukowany szkic Weber-Hiriakowej o Nocach $i$ dniach. Po raz pierwszy pisała ona już o Bogumile i Barbarze w 1932 roku. Widziała wtedy w powieści postaci „maleńkich ludzi” i górujące nad nimi ciemne oblicze życia, a relacje między małżonkami (obcość, „samotność we dwoje”) interpretowała niewątpliwie przez pryzmat własnego, nieudanego małżeństwa ${ }^{50}$. Maszynopis powstał już po

${ }^{48}$ D. F iło s o fo w, Dezintoksikacyja. Jw., 1932, nr 17.

49 Streszczenie odpowiedzi danej Fiłosofowowi przez pisarkę zob. D ą b r o w s k a, Dzienniki, t. 2 , s. 56-57.

${ }^{50}$ A. Ług a now [Je. We be r-Hi r i a k ow a], Pieried licom żyzń. „Za Swobodu!” 1932, nr 1 . 
wydaniu całości, a więc w 1934 lub 1935 roku. Niewykluczone, że przeznaczony był do wygłoszenia w Domku w Kołomnie, ale wygłoszony nie został. Może zakwestionował go sam Fiłosofow?

O ile w drukowanej recenzji Weber-Hiriakowa umieszczała powieść Dąbrowskiej w tradycji tołstojowskiej, o tyle w szkicu późniejszym zdecydowanie dominują porównania do Dostojewskiego, do Biednych ludzi.

Po wydaniu Nocy i dni rozpoczyna się kryzys przyjaźni intelektualnej, spowodowany przede wszystkim pretensjami Fiłosofowa wobec Dąbrowskiej jako publicystki. List z 18-20 VIII 1935 jest sążnistą polemiką z jej artykułem o profesji pisarskiej ${ }^{51}$. Na niektóre zarzuty autorka odpowiedziała $\mathrm{w}$ druku ${ }^{52}$, na inne w liście prywatnym (nie wysłanym?), który zachował się w archiwum Dąbrowskiej.

Szczegółowemu przedstawieniu zarzutów Fiłosofowa trzeba by poświęcić oddzielne studium, analizując je w zestawieniu z tezami autorki Nocy i dni. Warto w każdym razie podkreślić, że nieraz się rozmijali w dialogu, gdy każde z osobna kontynuowało własne wątki, co okazywało się źródłem kolejnych nieporozumień. W zasadzie przecież Fiłosofow był zwolennikiem intuicjonizmu i zbędna była jego tak zaciekła obrona. Przyjaciel zarzucił też Dąbrowskiej powierzchowną znajomość twórczości literackiej i filozofii Tołstoja i nierosyjski punkt widzenia. Pisarka odpowiedziała:

Tak jak gniew Pana, że ośmielam się wspomnieć o Tołstoju, niczego w etom nie ponimaja, przypomina mi gniew Kridla na to, że Pan ośmielił się pisać o Mickiewiczu (i, być może, źródło Pańskiej irytacji jest to samo), tak to, co Pan pisze z taką zjadliwością i ukrytą pogardliwością o Abramowskim, prowokuje we mnie swego rodzaju „Kridlizm”.

Tu zaczyna się obszerna, żarliwa obrona Edwarda Abramowskiego:

Jeśli w Polsce Abramowski nie jest znany, to nie dlatego, aby nie był tego wart, tylko że go znać nie chcemy, ponieważ nie lubimy głębi i tragiczności. Nie lubimy też rzeczy nie wykończonych i nie zaokrąglonych, ani bezapelacyjnych wymagań, a Abramowski był ich pełen ${ }^{53}$.

W sumie najbardziej bolesne zarzuty Fiłosofowa można streścić następująco: autorka wpadła w fałszywy ton, posługuje się nie swoim językiem i porusza zagadnienia akademickie, do czego nie jest intelektualnie przygotowana (list z 1820 VIII 1935, F 83-90). W kolejnym liście Fiłosofow wyjaśnia Dąbrowskiej wprost, że powinna „pisać jak artysta, a nie jak profesor” (list z 26 VIII 1935, F 91) i że nigdy nie prześcignie wiedzą ani erudycją Władysława Tatarkiewicza.

Rok później Fiłosofow komentując artykuł polemiczny Dąbrowskiej, zamieszczony w „Obliczu Dnia” ${ }^{4}$, zastanawia się, jak można „n a g r u n c i e p s y c h ol o g i i dyskutować z komunistami, w dodatku przy ludziach" (list z 22 V 1936, F 94).

${ }^{51}$ M. D ą b r o w s k a, Zawód literacki jako stużba społeczna. „Marchołt” 1934/35, nr 4. Przedruk w: D ą b r o w s k a, Pisma rozproszone, t. 2. Artykuł jest wersją odczytu, wygłoszonego przez autorkę Nocy $i$ dni kilkakrotnie (m.in. 9 V 1935 w Bibliotece Narodowej w Warszawie); Fiłosofow prawdopodobnie polemizuje jednak z wersją publikowaną.

52 M. D ą brow s k a, Na marginesie nie drukowanej polemiki. „Marchołt” 1935/36, nr 3. Przedruk w: D ą brow s k a, Pisma rozproszone, t. 2. skiego).

${ }^{53}$ M. D ą b row s k a, list do D. Fiłosofowa, z 22 VIII 1935 (Bibl. Uniwersytetu Warszaw-

${ }^{54}$ M. D ą b ro w s k a, Próba wyjaśnienia. „Oblicze Dnia” 1937, nr 7. 
W listach Fiłosofowa do Dąbrowskiej i Stanisława Stempowskiego wśród tematów literackich dominującym jest jej dorobek artystyczny. Poniekąd łączy się z nim też temat Elizy Orzeszkowej - jej biografii, twórczości i poglądów.

12 VIII 1928 Fiłosofow pisał:

Właśnie ,jednym tchem” przeczytałem Meira Ezofowicza Orzeszkowej. Bardzo lubię tę kobietę! (choć w młodości nienawidziłem literatury „tendencyjnej” i byłem zwolennikiem „sztuki dla sztuki”). Powieść bardzo trafiła mi do serca, bo bardzo lubię Żydów i wydaje mi się, że ich rozumiem. [F 35]

Nie była to tylko deklaracja. Fiłosofow zawsze zdecydowanie przeciwstawiał się antysemickim klimatom. Z tego powodu, jeszcze przed rewolucją, doprowadził do wykluczenia z udziału w petersburskich Spotkaniach Religijno-Filozoficznych wybitnego pisarza Wasilija Rozanowa. To też zmusiło Fiłosofowa do wystosowania w r. 1929 Listu otwartego do pisarzy polskich ${ }^{55}$, w związku z odbywającym się w Poznaniu zjazdem literatów, który powinien, jego zdaniem, potępić ekscesy antysemickie, do jakich doszło w tym samym czasie i w tymże mieście. Apel ten przeszedł bez echa. W roku 1936 Fiłosofow gratulował Dąbrowskiej jej artykułu Doroczny wstyd ${ }^{56}$. ,Tak, jesteśmy winni wszyscy ${ }^{57}$. Zdumiewa mnie bierność polskiego społeczeństwa. Czym to wytłumaczyć - nie wiem" (list z 26 XI 1936, F 96). Trzeba dodać, że Fiłosofow był podobnie jednomyślny w kwestiach polskiego nacjonalizmu z Jerzym Stempowskim. We wstępie do przedruku jego artykułu z „Głosu Prawdy” pisał o autorze:

jest [J. Stempowski] przedstawicielem tego radykalnego nurtu polskiej myśli politycznej, który, z jednej strony, nie jest szowinistyczny, a z drugiej - wyzbyty jest wszelkich skłonności antysemickich. Prócz tego, zarówno sam autor, jak i organ, w którym zamieścił ten artykuł, należą do zwolenników ukraińskiego ruchu niepodległościowego ${ }^{58}$.

Można powiedzieć, że po lekturze Meira Ezofowicza rozpoczął Fiłosofow systematyczne studia nad Orzeszkową i jej epoką, konsultując się w kwestiach szczegółowych ze Stanisławem Stempowskim. Znajdował wiele podobieństw między postawą polskiej pisarki a postawami jej rosyjskich rówieśników, przedstawicieli ,bijącej się w piersi szlachty”. Szczególną analogię znajdował między Orzeszkową a własną matką.

Matka moja uratowała Wierę Zasulicz, istnieje legenda, że przyczyniła się do ucieczki Kropotkina, tak jak Orzeszkowa woziła Traugutta. [...] Orzeszkowa połączyła wiarę w „komórkę" z praktycznym idealizmem i patriotyzmem, i moja matka także. Dalej, na starość matka moja też odczuwała „chłód” otoczenia (tak jak Pan i ja teraz!). [list z 2 VII 1932, F 57]

Przyczynę tego chłodu, a ściślej mówiąc, obojętności następców Fiłosofow thumaczy dyktatem polityki i radykalizacją światopoglądową. Oto zarówno szlachta ,pokutująca”, jak i ,nie pokutująca” wydawały się młodym już równie zbędne. Poza tym ,nadeszło zmęczenie złą sztuką tendencyjną, pojawiła się »sztuka dla

55 D. F i o s o fo w, List otwarty do pisarzy polskich. „Wiadomości Literackie” 1929, nr 24.

${ }_{56}$ M. D ą b ro w s k a, Doroczny wstyd. „Dziennik Popularny” 1936, nr 43.

${ }^{57}$ Zdanie napisane po polsku.

${ }^{58}$ R e d. [D. Fiło s o fow], O diele Szwarcbarda. Wstęp w: J. S. [J. S t e m pow ski], Process Szwarcbarda. „Za Swobodu!” 1927, nr 259 (przekład artykułu z „Głosu Prawdy”〈1927, nr 297〉). 
sztuki«. To było przyczyną cierpień Orzeszkowej u schyłku życia" (list z 2 VII 1932, F 59).

Sam Fiłosofow przyznaje, że po sześćdziesiątce z sentymentem myśli o tamtym pokoleniu ,jak o rycerzach »Pięknej Pani « ${ }^{59}$, jak o romantykach »Błękitnego Kwiatu « ${ }^{60}$ " (list z 2 VII 1932, F 59). Takie nastawienie sprawiło, że interesowały go najdrobniejsze szczegóły biografii Orzeszkowej.

W listach pisanych pod koniec lat trzydziestych, już po ukazaniu się wszystkich tomów Nocy i dni, Fiłosofow starał się w pewien sposób wpływać na Dąbrowską, kierować jej talentem. Posługiwał się przy tym przykładem Orzeszkowej ${ }^{61}$. W pozytywnym i negatywnym sensie:

Orzeszkowa nagadała i napisała wiele głupstw, ale była na dobrej drodze, jako pisarka zawsze służyła swojemu narodowi. Była w niej p ra w d a, niestety źle wyrażona, bo nie miała dość talentu, artyzmu do realizacji tego, co zamierzyła. Jeż (pierwsze dwa tomy wspomnień) ${ }^{62}$ miał, oczywiście, większy talent. [list z 25 IV 1938, F 97]

Czy pisząc „wiele głupstw”, Fiłosofow nie miał na myśli opowiadań Dąbrowskiej publikowanych po Nocach $i$ dniach? Podejrzewam, że to właśnie chciał zasugerować, choć cenił niektóre z wcześniejszych opowiadań Dąbrowskiej, a jedno przetłumaczył na rosyjski ${ }^{63}$. Jeszcze po lekturze Nocy $i$ dni skierował takie słowa do Zofii Dobrowolskiej: „Ona nic już więcej na takim poziomie nie napisze” ${ }^{64}$.

Fiłosofow rozumiał jednak, że doskonałość nie jest dana pisarzowi na zawsze i utwory słabe nie podważają arcydzieł. W liście do Stanisława Stempowskiego stwierdzał, że Orzeszkową przyjmuje en bloc i wybacza jej ,nie tylko grzechy »kochliwości«, ale też (co znacznie ważniejsze), grzechy jej t w ó r c z o ś c i (Boże, jakie straszne to jej Ad astra!). Ale napisała przecież Nad Niemnem! I za to należy wybaczyć jej Ad astra. W ogóle nie ma na świecie doskonałości”" (list z 20 VIII 1938, F 112).

W ostatnich dniach sierpnia 1939 Dąbrowska otrzymała znów długi list od Fiłosofowa, tym razem zawierający pretensje wobec wydanego właśnie dramatu Geniusz sierocy, którego egzemplarz ofiarowała mu w maju ${ }^{65}$. Przede wszystkim były to uwagi dotyczące historii XVII wieku. Rosjanin bardzo krytycznie odnosił

59 Aluzja do motywu miłości rycerskiej i do cyklu pt. Wiersze o Pięknej Pani (1901-1902) A. Błok a.

${ }^{60}$ Aluzja do motywu z powieści N o va lis a Heinrich von Ofterdingen (ok. 1800).

${ }^{61}$ Nie znamy ówczesnej reakcji Dąbrowskiej na próbę porównania jej z Orzeszkową. Po wojnie wszelkie tego rodzaju próby (ze strony J. Stempowskiego czy Cz. Miłosza) zdecydowanie torpedowała.

${ }^{62}$ T. T. J e ż [Z. M iłk o w s k i], Od kolebki przez życie. Wspomnienia. Do druku przygotował A. Le wak. Wstępem poprzedził A. B rü c kn e r. T. 1-3. Kraków 1936-1937.

${ }^{63}$ Ksiadz Filip. Przekład z r. 1930, nie opublikowany, tekst zaginiony.

${ }^{64}$ Cyt. za: J. Ti m o s z e w i c z, Fiłosofow - Czapski-Stempowski. „Kultura” 1998, nr 4.

${ }^{65}$ Dedykowany egzemplarz jest w posiadaniu B. Mikułowskiej. Dedykacja brzmi:

Dymitrowi Fiłosofowowi

jednemu $\mathrm{z}$ rodu sierocych geniuszów

Jego rosyjskiej ojczyzny ofiarowuje

Warszawa 29 V 1939 r. Maria Dąbrowska 
się w nich do rządów Władysława IV, który, jego zdaniem, był władcą anachronicznym, nie wyczuwającym wielkich przemian dokonujących się w Europie Zachodniej, gdzie tworzyły się nowoczesne państwa, ani na Wschodzie, gdzie błysnął wtedy imperialny geniusz Iwana Groźnego (list z 22 VIII 1939, F 125-127).

Pomimo wielu różnic, gorzkich wyrzutów, jakich Fiłosofow nie szczędził Dąbrowskiej, ich dialog trwał do końca w intelektualnym i emocjonalnym napięciu.

Rok po napisaniu tego listu Dmitrija Władimirowicza Fiłosofowa nie było już wśród żywych. O jego śmierci zawiadomiła Dąbrowską Aniela Zagórska. Tydzień później, 11 VIII 1940, pod wpływem relacji Czapskiej, która kilka tygodni spędziła przy konającym, autorka Nocy $i$ dni zapisała w dzienniku:

Prawdziwie tragiczny los tego człowieka. Mój Boże - człowiek jest tak otępiały, że nawet nie ma siły zapłakać. Tylko strzępy wspomnień nastręczają się plastycznie: Jaworze - jakeśmy tam w 1928 roku p. Dymitra ściągnęli, jak mu tam się podobało. Nie ma już ani Jaworza, ani Jerzego Cz[ekanowskiego], ani Dymitra. Nie ma już prawie nas ${ }^{66}$.

Bez wątpienia - Fiłosofow dzięki Stanisławowi Stempowskiemu i Marii Dąbrowskiej szybciej mógł zaznajomić się z Polską, jej historią, literaturą, problemami II Rzeczypospolitej, a także po prostu było mu nieco łatwiej znosić trudności emigracyjnego życia i chorobę. Trudno ocenić, jaki rzeczywisty wpływ wywarł Fiłosofow na Dąbrowską, na jej poglądy i warsztat pisarski. Jedno wydaje się pewne: obok Stanisława Stempowskiego i Henryka Józewskiego był tym, który kształtował jej pogląd na Rosję i komunizm, co pozwoliło pisarce raczej bez szwanku i z podniesioną głową przejść najgorsze lata powojenne.

\section{Abstract}

PIOTR MITZNER

(Cardinal Stefan Wyszyński University in Warsaw)

\section{A DIFFICULT FRIENDSHIP. \\ DMITRY FILOSOFOV - MARIA DĄBROWSKA - STANISŁAW STEMPOWSKI}

The article discusses Maria Dąbrowska's and Stanisław Stempowski's contacts with a Russian critic Dmitry Filosofov in the period of Filosofov's stay in Poland in 1920s and 1930s. Minor figures of the relations are Jerzy Stempowski and Filosofov's close collaborators. The main source are Filosofov's letters to Dąbrowska and to Stanisław Stempowski, which offer a testimony to their profound friendship and deep ideological and mental disparities. An important thread of the research is the process of composing of Night and Days which Filosofov greatly appreciated, keeping a distance from Dąbrowska's journalistic commentaties. However they were open, tolerant, and their views on their home cultures proved to be far from radically nationalistic, there were also misunderstandings between them following from the traditional Polish-Russian controversies. In the final analysis, the misunderstandings failed to conceal their true friendship and intellectual conformity.

${ }^{66}$ D ą b r o w s k a, Dzienniki, t. 2, s. 339. 